\title{
STRATEGI PEMANFAATAN KEUNGGULAN KOMPARATIF DALAM PENYEDIAAN CALON INDUK SAPI PERAH DI JAWA BARAT
}

\author{
Sri Rahayu, Cecep Firmansyah, dan Sondi Kuswaryan \\ Fakultas Peternakan Universitas Padjadjaran \\ E-mail: yukiroring@yahoo.com
}

\begin{abstract}
ABSTRAK Penelitian ini bertujuan untuk mengungkap keunggulan komparatif dan strategi pemanfaatannya dalam penyediaan induk sapi perah di Jawa Barat. Metode penelitian yang digunakan adalah survey di beberapa wilayah sentra dan non sentra budidaya sapi perah di Jawa Barat. Responden peternak ditentukan dengan multy stage, yaitu: tahap-1 menentukan jumlah sample (n), tahap-2 menentukan jumlah sample pada masingmasing lokasi (ni) menggunakan proporsional allocation sampling method, dan tahap-3 pengambilan sampel untuk masing-masing lokasi menggunakan simplerandom sampling. Jumlah sampel secara keseluruhan adalah sebanyak 65 orang. Teknik analisis yang digunakan merupakan perpaduan antara analisis kualitatif dan kuantitatif. Keunggulan komparatif dianalisis dengan teknik scoring menggunakan likert scale, dan location quotien. Faktor penentu penyediaan calon induk sapi perah dianalisis menggunakan perspective analysis. Strategi pemanfaatan keunggulan komparatif ditentukan dengan SWOT analysis. Hasil penelitian menujukkan bahwa : (1) Keunggulan komparatif wilayah dalam pengembangan usaha rearing sapi perah menurut urutan tertinggi sampai terendah adalah ketersediaan: (a) pakan hijauan, (b) jumlah tenaga kerja, dan (c) pedet sapi perah betina, (2) seluruh wilayah memiliki keunggulan komparatif berbeda-beda menurut indeks perbandingan relatif, (3) faktor-faktor penentu pengembangan usaha rearing: (a) kebijakan pemerintah, (b) eksistensi petugas/ pembina, dan (c) sumberdaya manusia dan teknologi, dan (4) strategi pemanfaatan keunggulan komparatif dalam penyediaan calon induk sapi perah di Jawa Barat diarahkan pada pengembangan usaha rearing sapi perah berkelanjutan didukung dengan berbagai kebijakan yang saling memperkuat satu sama lain. Fokus program diupayakan melalui pengembangan kualitas pembinaan, kualitas SDM peternak, peningkatan adopsi teknologi dan inovasi rearing sapi perah.
\end{abstract}

Kata Kunci : Strategi, penyediaan induk sapi, dan keunggulan komparatif

\section{STRATEGY OF UTILIZATION COMPARATIVE ADVANTAGES TO PROVIDING OF DAIRY CATTLE HEIFER IN WEST JAVA}

ABSTRACT This study aims to reveal the comparative advantage in the provision and utilization strategies of dairy cows in West Java. This research used survey method, the survey conducted in some centers and non-centers region of dairy cattle smallholder in West Java Province.Respondents farmers determined by multy stage, namely: stage-1 determines the number of samples (n), stage-2 determines the number of samples in each location (ni) using the proportional allocation sampling method, and stage-3 samples for each location using simple random sampling.The number of respondents much as 65 persons. This research used a combination of qualitative and quantitative analysis. Comparative advantages are analyzed by using a likert scale scoring techniques, and location quotien analysis (LQ). Factors determining the provision of heifer cow dairy analyzed using a analysis perspective model. Strategic utilization of comparative advantage is determined by the SWOT analysis. The results of the research that: (a) The comparative advantage of rearing business development are the potential forage production, and availability of human resources, (b) the determinants factor are the availability of human adviser, quality of human resources, technology and inovation, and (c) The strategies utilization of comparative advantage in West Javaare directed to the development of a sustainable dairy cattle rearing business, supported by various policies that reinforce each other.The focus of the program effort by developing quality coaching, quality of farmer resources, increased adoption of technology and innovation of rearing dairy cows.

Key Words : Strategy, providing of dairy cows, comparative advantage,

\section{PENDAHULUAN}

Induk sapi perah merupakan faktor produksi utama dalam usaha sapi perah, produksi dan produktivitasnya susu sangat tergantung dari kualitas induk sapi. Usaha peternakan sapi perah dalam pengembangan jangka panjang sangat tergantung pada ketersediaan induk, sehingga pasokan calon indukk sapi perah yang kontinyu menjadi jaminan keberlangsungan usahanya.

Jumlah peternak sapi perah yang melakukan usaha pembesaran pedet betina relatif sedikit, pedet yang dihasilkan tidak dibesarkan untuk tujuan replacement stock melainkan di jual ke bandar. Umumnya pedet yang dilahirkan dan dijual tersebut berasal dari induk-induk sapi yang produktivitasnya relatif tinggi berkisar antara 15 - 25 liter/ekor/ hari. Alasan peternak menjual pedet betina adalah karena keterdesakan kebutuhan finansial keluarga, alasan lainnya adalah keterbatasan dana untuk biaya operasional rearingdan dianggap usaha ini lambat menghasilkan uang, dan keterbatasan tenaga kerja keluarga, sehubungan sebagian besar peternak dalam usahanya mengandalkan tenaga kerja keluarga, serta intensitas bekerja pada usaha sapi perah relatif tinggi

Para peternak secara umum membeli calon induk sapi perah dari luar untuk mengganti sapi yang diafkir. Umumnya membeli dari peternak lain, bandar, bahkan mendatangkan dari luar wilayah Jawa Barat. Fakta di lapangan menujukan produktivitas induk sapi perah yang berasal dari luar sangat rendah 
berkisar antar $4-10$ liter/ekor/hari, kondisi ini banyak dikeluhkan oleh para peternak, terutama yang memperoleh bantuan sapi perah dari pemerintah. Pemerintah dalam pengadaan calon induk sapi perah mensyaratkan harus datang dari luar Jawa Barat, dengan tujuan untuk meningkatkan populasi.

Produktivitas usaha yang menurun dan calon induk pengganti sapi afkir produktivitasnya relatif rendah, secara agregat berdampak pada penurunan produksi susu, dan kondisi ini menjadi tidak menarik bagi para peternak untuk melakukan usaha. Calon induk sapi perah menjadi persoalan penting dalam membengun peternakan sapi perah berkelanjutan, karena itu perlu adanya solusi yang efektif, sehingga perlu ada kajian ilmiah yang mengungkap persoalan tersebut

Pelaksanaan usaha rearing pedet betina sapi perah dinilai peternak kurang memberikan insentif, dan lambat menghasilkan uang, sehingga mereka lebih memilih menjual pedet betina, dan membeli calon sapi pengganti induk afkir. Penjualan pedet betina ini berisiko terhadap hilangnya potensi genetik sapi perah produktif dalam menghasilkan susu di Jawa Barat, karena yang dijual adalah pedet pedet yang diturunkan dari induk yang produktivitasnya tinggi. Pola penyediaan calon induk pengganti sapi perah afkir seperti ini dalam jangka panjang akan menurunkan produktivitas susu di Jawa Barat dan pengembangan usaha peternakan sapi perah pun akan terhambat, sementara itu kebutuhan akan susu terus meningkat sejalan dengan laju pertumbuhan penduduk. Terhambatnya kesinambungan usaha sapi perah, juga dapat berdampak pada penurunan lapangan usaha, dan potensial menambah jumlah orang menganggur.

Jawa Barat secara kewilayahan masih memiliki daerah-daerah yang prospek dikembangkan untuk wilayah usaha rearing sapi perah. Wilayah-wilayah tersebut masih memiliki potensi penambahan jenis ternak ruminansia, sehubungan masih banyak hijauan makanan ternak yang belum termanfaatkan, dan banyak penduduk yang memilki pengalaman beternak sapi. Mengatasi persoalan penyediaan sapi perah dapat dilakukan dengan menggeser lokasi usaha rearing ke lokasi non sentra sapi perah yang mempunyai keunggulan komparatif. Diharapkan pergeseran lokasi usaha ini dapat memperluas lapangan usaha, dan penyerapan lapangan tenaga kerja baru, serta yang paling utama adalah Jawa Barat dapat menghasilkan calon induk sapi perah sendiri. Untuk upaya tersebut, maka diperlukan suatu kajian yang dapat mengungkap potensi wiilayah yang menjadi keunngulan komparatif, serta pelaksanaan rearing dipengaruhi banyak faktor, dan tentunya membutuhkan strategi pengembangannya

a. Apa saja yang menjadi keunggulan komparatif Jawa Barat dalam penyediaan calon induk sapi perah.

b. Faktor-faktor apa saja yang menjadi penentu penyediaan calon induk sapi perah

c. Bagaimana strategi pemanfaatan keunggulan komparatif untuk penyediaan calon induk sapi perah secara berkelanjutan

Tujuan penelitian ini adalah untuk :

a. Menganalisis keunggulan komparatif Jawa Barat dalam penyediaan calon induk sapi perah.

b. Menganalisis Faktor-faktor penentu penyediaan calon induk sapi perah

c. Menyusun strategi pemanfaatan keunggulan komparatif untuk penyediaan calon induk sapi perah secara berkelanjutan

\section{METODE}

Penelitian ini menggunakan metode survey. Kegiatan survey dilaksanakan di beberapa wilayah sentra (Lembang dan Pangalengan) dan wilayah non sentra budidaya sapi perah yaitu cisalak Subang, Rancakalong Sumedang, Sukanagara Cianjur, Pagerageung Tasikmalaya, Sukaratu Tasikmalaya, Panjalu Ciamis, Sukamantri Ciamis. Lokasi penelitiannya ditentukan secara purposive dengan pertimbangan : (a) Lembang dan Pangalengan merupakan wilayah sentra budidaya sapi perah dan membutuhkan suplay calon induk relatif lebih banyak dari wilayah sentra sapi perah lainnya, (b) Ketujuh lokasi bukan sentra sapi perahmemiliki potensi agroklimat yang sesuai dengan sapi perah dan dinilai memiliki keunggulan komparatif,

Responden dalam penelitian ini diperoleh melalui beberapa tahap, yaitu : tahap-1 menentukan jumlah sample (n), tahap-2 menentukan jumlah sample pada masing-masing lokasi (ni) menggunakan proporsional allocation sampling method. dan tahap-3 adalah pengambilan sampel untuk masing-masing lokasi dengan menggunakan simple random sampling method. Jumlah responden sebanyak 65 orang yang terdiri dari 21 orang peternak di wilayah non sentra budidaya sapi perah, 25 orang peternak di wilayah sentra sapi perah, 9 orang dari dinas teknis yang membidangi peternakan di wilayah penelitian, dan 10 orang pemangku jabatan pada Dinas Peternakan Provinsi Jawa Barat.

Analisis keunggulan komparatif dengan cara deskriptif dengan memadukan pendekatan kualitatif dan kuantitatif, yaitu : (a) untuk ketersediaan variabel-variabel sosial, budaya, kelembagaan, ekonomi dan ketersediaan komponen entrepreneurship dengan teknik scoring menggunakan likert scale, dan (b) ketersediaan pedet sapi perah betina, jumlah tenaga kerja dan pakan hijauan menggunakan location quotien analysis (LQ). Faktor penentu penyediaan calon induk sapi perah dianalisis secara kualitatif dan kuantitatif dengan menggunakan model perspective analysis, pada model ini diterapkan pendekatan partisipatif peserta FGD dalam menentukan sejumlah variabel yang menjadi faktor penentu. Strategi pemanfaatan keunggulan komparatif dianalisis menggunakan model SWOT analysis.

\section{HASIL DAN PEMBAHASAN}

\section{Keunggulan Komparatif Wilayah dalam Penyediaan Calon Induk Sapi Perah}

Para peternak di wilayah sentra budidaya sapi perah hanya sebagian kecil yang melakukan usaha rearing 
pedet betina, umumnya pedet yang dihasilkan dijual. Faktor-faktor penyebab tidak melakukan rearing, antara lain karena keterbatasan tenaga kerja keluarga, modal usaha kecil, dan penerimaan usaha dinilai lambat dibandingkan dengan memelihara induk sapi perah. Hasil penelitian Sophia, P. (2013) di Cisarua Kabupaten Bandung Barat, terdapat beberapa alasan peternak yang tidak melakukan usaha rearing, yaitu lama menghasilkan susu, harga susu mahal, risiko tinggi, membutuhkan tambahan biaya, dan menjual pedet betina lepas sapih karena terdesak kebutuhan ekonomi keluarga. Faktor penyebab yang tidak kalah pentingnya adalah ketersediaan pakan berupa rumput, jerami dan leguminose di sentra budidaya sapi perah sudah jauh berkurang, dan secara empirik di beberapa sentra budidaya sapi perah seudah terjadi over populasi, fakta ini diperkuat oleh banyaknya peternak sapi perah yang menyabit rumput dan jerami ke daerah non sentra budidaya sapi perah dan cenderung membutuhkan waktu yang cukup lama sampai memenuhi kebutuhan pakan untuk sejumlah sapi perah yang mereka pelihara, apalagi pada musim kemarau dimana produktivitas pakan hijauan jauh lebih rendah.

Daerah non sentra budidaya sapi perah di Jawa Barat masih banyak yang memilki agroklimat yang masih pada kisaran kemampuan adaftasi fisiologis sapi perah, seperti di Kabupaten Subang, Sumedang, Cianjur dan Tasikmalaya. Dearah non sentra budidaya sapi perah umumnya masih dapat menampung tambahan populasi ternak ruminansia, karena produksi pakan hijaannya berlebih, bahkan daerah tersebut menjadi tujuan menyabit rumput bagi para peternak sapi perah. Derah non sentra budidaya sapi perah ini dapat dijadikan alternatif bagi pengembangan usaha rearing pedet betina sapi perah untuk tujuan replacement stock untuk usaha peternakan sapi perah (UPSPR) di Jawa Barat, karena memilki keunngulan komparatif yang salah satunya adalah pakan hijauan. Kondisi fisik dan aksesibilitas daerah non sentra budidaya sapi perah dapat dilihat pada Tabel 1 .

Tabel 1. Aksesibilitas dan Kondisi Fisik Daerah Non Sentra Budidaya Sapi Perah

Ketersediaan pakan hijauan secara lokal merupakan bagian dari potensi wilayah bagi pengembangan usaha rearing sapi perah. Pakan hijauan di daerah non sentra budidaya sapi perah juga harganya akan lebih murah, sehingga pelaksanaan

\begin{tabular}{|c|c|c|c|c|}
\hline No & Kec. & Kab. & Aksesibilitas & Kondisi Fisik Lahan \\
\hline 1 & Cisalak & Subang & Baik & $\begin{array}{l}\text { Berbukit dan sebagian datar, } \\
\text { suhu dingin }\end{array}$ \\
\hline 2 & Rancakalong & Sumedang & Baik & Berbukit, lokasi datar \\
\hline 3 & Sukanagara & Cianjur & Kurang baik & $\begin{array}{l}\text { Berbukit, lokasi sebagian } \\
\text { datar, suhu relatif dingin }\end{array}$ \\
\hline 4 & Pagerageung & Tasikmalaya & Baik & $\begin{array}{l}\text { Sebagian datar terletak di } \\
\text { pebukitan dataran tinggi, } \\
\text { suhu relatfdingin }\end{array}$ \\
\hline 5 & Sukaratu & Tasikmalaya & Baik & $\begin{array}{l}\text { Dataran tinggi, daerah } \\
\text { perbukitan, suhu relatiff } \\
\text { dingin }\end{array}$ \\
\hline 9 & Panjalu & Ciamis & Baik & $\begin{array}{l}\text { Daerah dataran tinggi, suhu } \\
\text { relatif dingin, ketersediaan } \\
\text { air memadai }\end{array}$ \\
\hline 10 & Sukamantri & Ciamis & Kurang Baik & $\begin{array}{l}\text { Daerah dataran tinggi, suhu } \\
\text { relatif dingin, ketersediaan } \\
\text { air relatif kurang pada } \\
\text { musim kemarau }\end{array}$ \\
\hline
\end{tabular}

rearing di daerah ini dengan menggunakan pakan lokal dapat menunjang efisiensi usaha, dan menghasilkan calon pengganti (replacement stock) induk sapi perah menjadi lebih murah dibandingkan biaya produksi di daerah sentra budidaya sapi perah. Hasil observasi memberikan gambaran harga rumput di daerah sentra budidaya sapi perah berkisar antara Rp. 350/kg - Rp. 450/kg lebih mahal dibandingkan di daerah non sentra budidaya sapi perah yag berkisar antra Rp. 250,kg - Rp. 350.kg, perbedaan harga ini disebabkan adanya perbedaan biaya transportasi rumput.

Potensi produksi rumput di daerah sentra budidaya sapi perah cukup tinggi dan belum termanfaatkan seluruhnya. Potensi produksi pakan yang terdiri dari rumput, jerami padi, jerami jagung, jerami kedele, kacang hijau, kacang tanah untuk setiap daerahnya sebesar 22.262,6 \pm 8.732,9 ton bahan kering (BK) per tahun, sedangkan yang termanfaatkan 7.001,2 $\pm 3.160,1$ ton/BK/tahun atau baru sekitar 31,45\% dari potensi produksi pakan. Potensi penambahan ternak ruminansia yang didasarkan pada konsumsi pakan 9,1 kg/ST/hari, maka setiap derah masih dapat diintroduksi ternak ruminansia sebanyak 4.594,7 \pm 2.698,0 ST/tahun.

Kecamatan Sukaratu Kabupaten Tasikmalaya merupakan daerah dengan produksi pakan terbesar, sementara Kecamatan Sukamantri Kabupaten Ciamis adalah yang terkecil. Potensi penambahan ternak ruminansia dari seluruh daerah (lokasi penelitian) sebesar 32.163 ST/tahun, dimana potensi penambahan terbesar (9.203 ST/tahun) adalah Kecamatan Sukaratu, namun yang terkecil(1.377 ST/tahun) adalah Kecamatan Rancakalong Kabupaten Sumedang. Jumlah produksi pakan dan potensi penambahan ternak ruminansia, jika dimanfaatkan untuk pengembangan usaha rearing pedet betina sapi perah akan menghasilkan calon induk bibit sapi perah dalam jumlah yang cukup besar, dan dapat memberikan pasokan calon induk yang kontinyu, dapat mengatasi kekurangan calon induk (kuantitas dan kualitas) serta dapat menjamin sustainabilty usaha sapi perah. Potensi produksi pakan dan penambahan ternak ruminansia dapat dilihat pada Tabel 2 .

Tabel2. Potensi Produksi Pakan dan Potensi Penambahan Ternak di Daerah Non Sentra Budidaya Sapi Perah

Pengembangan usaha rearing sapi perah tidak cukup mengandalkan faktor fisik lingkungan dan produksi pakan di wilayah bersangkutan, namun perlu juga mendapat dukungan dari beberapa komponen dari sistem yaitu: kompenen cluster usaha

\begin{tabular}{llcccc}
\hline No Kecamatan & Kabupaten & $\begin{array}{c}\text { Potensi } \\
\text { Pakan } \\
\text { (ton } \\
\text { BK/tahun) }\end{array}$ & \multicolumn{1}{c}{$\begin{array}{c}\text { Populasi } \\
\text { (ST) }\end{array}$} & $\begin{array}{c}\text { Pemanfatan } \\
\text { (ton } \\
\text { BK/tahun) }\end{array}$ & $\begin{array}{c}\text { Potensi } \\
\text { Penambahan } \\
\text { (ST/tahun) }\end{array}$ \\
\hline 1 Cisalak & Subang & $26.003,50$ & $2.632,80$ & $8.744,85$ & 5.196 \\
2 Rancakalong & Sumedang & $13.920,90$ & $2.814,54$ & $9.348,50$ & 1.377 \\
3 Sukanagara & Cianjur & $22.437,10$ & $2.933,02$ & $9.742,02$ & 3.822 \\
4 Pagerageung & Tasikmalaya & $32.540,60$ & $2.965,16$ & $9.848,77$ & 6.832 \\
5 Sukaratu & Tasikmalaya & $33.188,60$ & 788,9 & $2.620,33$ & 9.203 \\
6 Panjalu & Ciamis & $15.900,70$ & $1.647,94$ & $5.473,64$ & 3.139 \\
7 Sukamantri & Ciamis & $11.846,80$ & 972,53 & $3.230,25$ & 2.594 \\
\hline
\end{tabular}


rearing (sistem sosial, budaya, kelembagaan, dan sistem ekonomi), komponen usaha (faktor produksi, proses produksi, produk rearing, manajemen usaha rearing), komponen entrepreneur (percaya diri, berorientasi pada tugas dan hasil, pengambil risiko, kepemimpinan, keorsinilan, dan berorientasi ke masa depan). Ketersediaan komponen cluster usaha rearing di lokasi penelitian masih dalam tingkatan rendah sampai sedang, sehingga dalam pengembangan usaha perlu ada upaya-upaya perbaikan (Tabel 3)

Tabel 3. Ketersediaan dan Kondisi sistem Kemasyarakatan di Daerah Non Sentra Budidaya Sapi Perah

Keterangan: $\mathrm{R}=$ Rendah, $\mathrm{S}=$ sedang, $\mathrm{T}=$ tinggi

Sumberdaya yang menjadi keunggulan komparatif pengembangan usaha rearing berdasarkan hasil analisis validasi adalah ketersediaan pedet sapi perah betina,

\begin{tabular}{llll}
\hline \multirow{2}{*}{$\begin{array}{c}\text { Komponen Cluster Usaha } \\
\text { Rearing }\end{array}$} & \multicolumn{3}{c}{ Keters ediaan } \\
\cline { 2 - 4 } & $\mathrm{R}$ & $\mathrm{S}$ & $\mathrm{T}$ \\
\hline$\square$ Sistem Sosial & & $\mathrm{X}$ \\
$\square$ Sistem Budaya & $\mathrm{X}$ & $\mathrm{X}$ \\
$\square$ Sistem Kelembagaan & $\mathrm{X}$ & \\
$\square$ Sistem Ekonomi & $\mathrm{X}$ & $\mathrm{X}$ &
\end{tabular}

ketersediaan jumlah tenaga kerja dan ketersediaan pakan hijauan. Indeks relatif skor sumberdaya memberikan gambaran bahwa ketersediaan hijauan memiliki keunggulan komparatif lebih besar dari keunggulan komparatif ketersediaan jumlah tenaga kerja dan ketersediaan pedet sapi perah betina (Table 4.)

Tabel 4. Urutan Keunggulan Komparatif Sumberdaya Menrut Indeks Ralatif

Keterangan : $\mathrm{n}$ wilayah $=7$

Pedet sapi pera betina merupakan sumberdaya dalam pengembangan usaha rearing sapi perah.

\begin{tabular}{|c|c|c|c|c|}
\hline No & Sumber Daya & $\begin{array}{c}\text { Jumlah } \\
\text { Skor }\end{array}$ & $\begin{array}{l}\text { Indeks } \\
\text { Relatif }\end{array}$ & Urutan \\
\hline 1 & $\begin{array}{l}\text { Ketersediaan } \\
\text { pedet sapi perah } \\
\text { betina }\end{array}$ & 9 & 0,47 & 3 \\
\hline 2 & $\begin{array}{l}\text { Ketersediaan } \\
\text { jumlah tenaga } \\
\text { kerja }\end{array}$ & 15,7 & 0,81 & 2 \\
\hline 3 & Ketersediaan & 19,3 & 1 & 1 \\
\hline
\end{tabular}

dalam hal ketersediaan pedet sapi perah betina adalah Kecamatan Cisalak Kabupaten Subang dibandingkan wilayah lainnya. Keunggulan ini terjadi, karena skor jumlah tenaga kerja dan pakan hijauan relatif kecil dibandingkan dengan skor ketersediaan pedet sapi perah betina, serta secara empirik wilayah ini memiliki kedekatan geografis denganwilayah sentra sapi perah yaitu Kecamatan Lembang Kabupaten Bandung Barat yang banyak menghasilkan pedet sapi perah. Kecamatan Cisalak ditinjau dari potensi produksi hijauan masih memungkinkan dikembangkannya usaha rearing, karena masih memiliki potensi penambahan ternak ruminansia sebesar 5.196 ST/tahun (Lihat Tabel 2). Wilayah lain yang memiliki indeks perbandingan relatif di atas 1 (satu) adalah Kecamatan Pagerageung di Kabupaten Tasikmalaya. Perbandingan keunggulan relatif dapat dilihat pada Tabel 5 .

Tebel 5. Indeks Perbandingan Relatif Keunggulan Komparaif Wilayah menurut Sumberdaya

Keterangan : W1 = Cisalak Subang, W2 = Rancakalong Sumedang, W3 = Sukanagara Cianjur W4 = Pagerageung Tasukmalaya, W5 = Sukaratu Tasikmalaya, W6 = Panjalu Ciamis, $\mathrm{W} 7=$ Sukamantri Ciamis

Peranan tenaga kerja sangat penting dalam usaha

\begin{tabular}{lcccccccc}
\hline No. & Sumberdaya & W1 & W2 & W3 & W4 & W5 & W6 & W7 \\
\hline 1 & $\begin{array}{l}\text { Ketersediaanpedet sapi } \\
\text { perah betina }\end{array}$ & 1,3 & 1 & 0,81 & 1,18 & 0,75 & 0,98 & 0,89 \\
2 & $\begin{array}{l}\text { Ketersediaanjumlah } \\
\text { tenaga kerja }\end{array}$ & 0,93 & 1,07 & 0,93 & 1,08 & 1,29 & 0,84 & 0,76 \\
3 & $\begin{array}{l}\text { Ketersediaan pakan } \\
\text { hijauan }\end{array}$ & 0,91 & 0,94 & 1,14 & 0,85 & 0,88 & 1,14 & 1,24 \\
\hline
\end{tabular}

peternakan sapi perah, dan umumnya tenaga kerja yang digunakan adalah tenaga kerja keluarga. Hasil penelitian Taslim (2011) menyimpulkan bahwa curahan tenaga kerja berkorelasi positif terhadap kepemilikan ternak sapi perah, dan berpengaruh nyata terhadap pendapatan peternak. Hasil penelitian tersebut memberikan gambaran bahwa ketersediaan jumlah peternak dan curahan tenaga kerjanya akan sagat menentukan terhadap skala usaha dalam pengembngan usaha rearing sapi perah. Wilayah yang memiliki keunggulan komparatif pada ketersediaan jumlah tenaga kerja adalah Kecamatan Sukaratu di Kabupaten Tasikmalaya. Keunggulan ini terbentuk, karena sumberdaya lain yang dimilikinya memiliki skor yang relatif lebih rendah dibandingkan dengan ketersediaan jumlah tenaga kerja.

Rumput dan jerami merupakan sumber pakan bagi pengembangan usaha sapi perah yang diperoleh dari produksi lahan pertanian, dan lahan kering lainnya. Penelitian Astuti, M., dkk. (2010) menyimpulkan bahwa hijauan, pakan dan faktor produksi lainnya dalam penelitian tersebut secara simultan berpengaruh nyata terhadap produksi susu. Hasil penelitian ini memberi gambaran bahwa pada usaha rearing pun sangat membutuhkan hijauan untuk tumbuh dan berkembang pedet betina sapi perah. Ketersediaan jumlah rumput dan jerami menjadi bagian penting yang perlu dipertimbangkan dalam konteks pengembangan usaha rearing sapi perah yang berkelanjutan, karena produksinya fluktuatif sejalan dengan adanya musim hujan dan musim kemarau. Produksi hijauan sangat kurang pada saat musim hujan, sehingga pada penyediaan pakan dengan sistem cut and carry, banyak peternak yang menyabit rumput ke daerah yang jangkauannya relatif jauh dan dalam waktu yang lama. Kondisi ini menjadi permasalahan, dan dapat menyebabkan usaha menjadi tidak efisien, bahkan kasus pada musim kemarau yang relatif panjang, 
biasanya populasi sapi perah menjadi berkurang, karena para peternak banyak yang menjual sapi-sapi peliharaannya. Wilayah yang memiliki keunggulan komparatif dalam penyediaan hijauan makanan ternak adalah Kecamatan Sukamantri Kabupaten Ciamis. Hasil analisis menujukan bahwa kecamatan Sukamantri memiliki potensi penambahan ternak ruminansia sekitar 9,203 $\mathrm{ST} /$ tahun.

Komponen usaha di daerah non sentra budidaya sapi perah pada penelitian ini meliput faktor produksi, proses produksi, produk rearing, manajemen usaha rearing, secara umum tingkat ketersediaannya berkisar antara tidak tersedia sampai tersedia. Khusus untuk komponen sub komponen manajemen usaha dari yang terdiri dari planing, organizing, actuating, dan controlling masih belum ada, sehingga pada pengembangan usaha rearing perlu upaya perbaikan melalui peningkatan pengetahuan terhadap arti penting fungsi manajemen usaha, dan peningkatan skill-nya.

Tabel 6. Skor Ketersediaan Komponen Usaha di Wilayah Non Sentra Budidaya Sapi Perah

Keterangan :

- $\mathrm{W} 1$ = Cisalak Subang, W2 = Rancakalong Sumedang, W3 $=$ Sukanagara Cianjur W4 = Pagerageung Tasukmalaya, W5 = Sukaratu Tasikmalaya, W6 = Panjalu Ciamis, W7 = Sukamantri Ciamis

- Katagori Wilayah Menurut Skor

\begin{tabular}{cccccccc}
$\begin{array}{c}\text { Komponen } \\
\text { Usaha }\end{array}$ & W1 & W2 & W3 & W4 & W5 & W6 & W7 \\
\hline Faktor Produksi & 18 & 16 & 17 & 16 & 16 & 15 & 14 \\
Proses Produksi & 10 & 9 & 10 & 11 & 7 & 7 & 7 \\
Produk Rearing & 1 & 1 & 1 & 1 & 1 & 1 & 1 \\
$\begin{array}{c}\text { Manajemen } \\
\begin{array}{c}\text { Saha Rearing } \\
\text { Sapi Perah }\end{array}\end{array}$ & 4 & 4 & 4 & 4 & 4 & 4 & 4 \\
$\begin{array}{c}\text { Jumlah } \\
\text { Kategori }\end{array}$ & M & CM & CM & CM & CM & CM & CM \\
\hline
\end{tabular}

Peternak dalam konteks pengembangan usaha rearing sapi perah merupakan individu pelaksana usaha itu sendiri, sehingga dalam pengembangannya menuju kesuksesan selayaknya para peternak memiliki ciri dan watak seorang entrepreneur.

$$
\begin{array}{ll}
18,0-25,1 & : \mathrm{SM}=\text { Ketersediaan sangat memadai } \\
25,2-32,3 & : \mathrm{CM}=\text { Ketersediaan cukup memadai } \\
32,4-39,5 & : \mathrm{M}=\text { Ketersediaan memadai } \\
39,6-46,7 & : \mathrm{M}=\text { Ketersediaan kurang memadai } \\
46,8-53,9 & : \mathrm{TM}=\text { Ketersediaan tidak memadai }
\end{array}
$$

Menurut Meredith, Geoffrey, et, al., 1992, ciri dan karakter seorang wirausaha meliputi: percaya diri, berorientasi tugas dan hasil, pengambil risiko, kepemimpinan, keorsinilan, dan berorientasi ke masa depan. Penilaian terhadap ciri-ciri dan watak entrepreneur responden menujukan bahwa ciri-ciri dan watak entrepreneur yang dimiliki para peternak masih dalam taraf rendah (Tabel 7). Kondisi ciriciri dan watak sebagai komponen entrepreneur para peternak, memberikan indikasi bawha dalam pengembangan usaha rearing perlu adanya upaya meningkatkan motivasi para peternak dalam berusaha melalui pendidikan non formal dan pelatihan. Upaya tersebut menjadi sangat strategis, karena menurut, Wasty Soemanto (1992) mengemukakan juga bahwa ciri-ciri seorang wirausaha adalah memiliki : moral tinggi, sikap mental wirausaha, kepekaan terhadap arti lingkungan, dan keterampilan wirausaha.

Tabel 7. Ketersediaan Komponen Entrepreneurship di Daerah Non Sentra Budidaya Sapi Perah

\section{Faktor Penentu Pemanfaatan Keunggulan

\begin{tabular}{|c|c|c|c|}
\hline \multirow{2}{*}{ Komponen Entrepreneurship } & \multicolumn{3}{|c|}{ Ketersediaan } \\
\hline & Rendah & Sedang & Tinggi \\
\hline$\square$ Percaya Diri & $\mathrm{X}$ & & \\
\hline Berorientasikan tugas dan hasil & $\mathrm{X}$ & & \\
\hline$\square$ Penga mbil risiko & $\mathrm{X}$ & & \\
\hline Kepemimpinan & $\mathrm{X}$ & & \\
\hline Keorisinilan & $\mathrm{X}$ & & \\
\hline Berorientasikan ke masa depan & $\mathrm{X}$ & & \\
\hline
\end{tabular} Komparatif}

Hasil perspective analysis menujukan bahwa faktor penentu pengembangan usaha rearing sapi perah adalah kebijakan, eksistensi petugas/ pembina,

sumberdaya manusia dan teknologi, keempat faktor ini memiliki pengaruh yang besar dengan tingkat ketergantungan yang relatif rendah dan berada pada Gambar 1.

Kebijakan pemerintah merupakan salah satu instrument dalam pembangunan, dengan demikian pengembangan usaha rearing sapi perah perlu didukung dengan kebijakan. Pada tingkat nasional telah terdapat kebijakan yang dapat dimanfaatkan dalam pengembangan usaa rearing sapi perah. Arah kebijakan pembangunan kementrian pertanian (pada point g), bahwa: "pembangunan kawasan komoditas terpadu secara vertikal dan/atau horizontal melalui konsolidasi usaha tani produktif berbasis lembaga ekonomi masyarakat yang berdaya saing tinggi di pasar lokal dan internasional", (Dirjen PKH, 2011). Arah kebijakan tersebut merupakan dasar bagi penyusunan regulasi dan rencana pengembangan sapi perah, termasuk subsistem usaha rearing sapi perah. Lebih lanjut, komoditas sapi perah menurut Dirjen PKH (2014) dari hasil Pramusrenbangtan dikategorikan sebagai komoditas strategis PKH, di Jawa Barat akan dikembangkan di Kawasan Cekungan Bandung, yaitu di Kabupaten Bandung, dan Kabupaten Bandung Barat.

Di Jawa Barat peningkatan produksi dan produktivitas sapi perah menjadi prioritas. Pada tahun 2010 telah banyak kegiatan yang ditujukan untuk prioritas tersebut antaa lain adalah : Kegiatan (a) Pengembangan dan Penguatan Perbibitan Ternak Sapi Perah di Balai Perbibitan dan Pengembangan Inseminasi Buatan Ternak Sapi Perah Bunikasih, (b) Pengembangan dan Penguatan Perbibitan Ternak Sapi Perah di BPT Sapi Perah \& HMT Cikole Lembang, dan (c) Penguatan Peternak Sapi Perah Guna Meningkatkan Produktivitas dan Kelancaran Distribusi Susu Sapi Perah Lokal (Gerimis Bagus), 
serta kegiatan lainnya. Kebijakan yang telah dikeluarkan oleh tingkat nasional, maupun pada tingkat Provinsi Jawa Barat, belum memberikan insentif bagi tumbuhkembangnya usaha rearing yang akan menghasilkan calon induk sapi perah, seperti tela dijelaskan bahwa produksi dan produktivitas sapi perah sangat ditentukan oleh ketersediaan dan kualitas calon induk sapi perah.

Gambar 1. Diagram Scatter Faktor-faktor Penentu Pengembangan Usaha Rearing Sapi Perah

Kebijakan pengembangan sapi perah tidak dapat berdiri sendiri, juga terkait dengan kebijakan dan

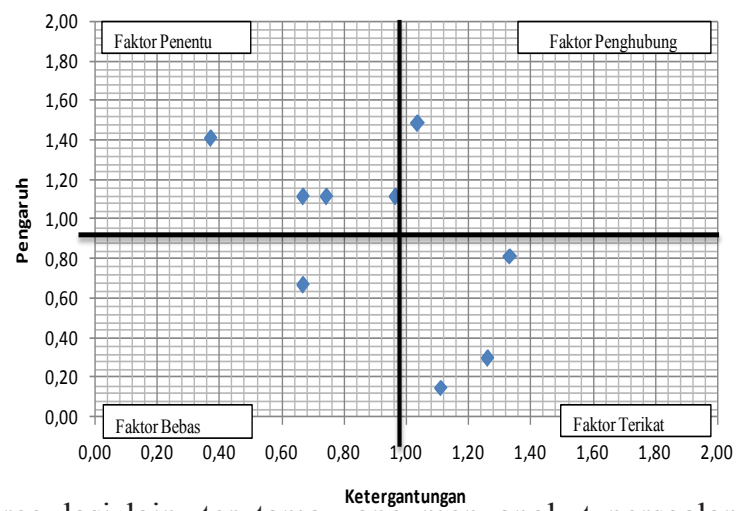

regulasi lain, terutama yang menyangkut persoalan tataruang (RTRW), kebijakan moneter, kebijakan perdagangan, bahkan juga terkait dengan regulasi internasional mengenai perdagangan bebas (free trade). Kebijakan yang ada saat ini belum memberikan penguatan terhadap kemajuan peternakan sapi perah. Hasil penelitian Yusdja, Y. (2005) pun menyimpulkan bahwa Kebijakan Makro tidak memberikan insentif bagi perusahaan koperasi maupun peternak swasta untuk berkembang.

Ketersediaan petugas/ pembina pada tatanan implementasi program pengembangan usaha rearing sapi perah eksitensinya memberikan pengaruh yang besar terhadap keberhasilan usaha. Petugas dan pembina memiliki fungsi sebagai fasilitator dalam pembangunan. Hasil penelitian, intensitas pembinaan dapat meningkatkan peran serta peternak dalam melakukan usaha. Penelitian Hendarto, E., dan Sri Mastuti, (1999) pada usahternak sapi perah menyimpulkan bahwa tingkat partisipasi peternak meningkat dengan adanya program pembinaan. Petugas da pembina juga berperan sebagai motivator, motivasi internal dan eksternal berpengaruh terhadap kinerja, sehingga tujuan pengembangan usaha akan tercapai. Berdasarkan hasil analisis, eksistensi petugas/ pembina memilki pengaruh yang besar dengan tingkat ketergantungan yang keci, sehingga eksistensinya menjadi faktor penentu dalam pengembangan usaha rearing sapi perah.

Sumberdaya (SDM) peternak merupakan pelaku usaha, hasil analisis menujukan bahwa kualitas SDM Peternak ini menjadi faktor penentu keberhasilan. Kualitas SDM peternak dapat dilihat dari tingkat pendidikan formal, pengalaman beternak. Responden penelitian ini hampir sebagian besar adalah lulusan sekolah dasar, dan sebagian lagi lulusan SLTP dan
SLTA, namun mereka umumnya telah berpengalaman mengelola sapi berkisar antara 5-23 tahun. Kualtas SDM berpengaruh positif terhadap kinerja usaha. Menurut kesimpulan penelitian Mukson, T., dkk. (2009) faktor SDM, yang terdiri dari umur peternak, dan pendidikan pada usahaternak sapi perah dapat meningkatkan produksi susu. Pertambahan umur dan tingkat pendidikan secara logais dapat meningkatkan pengalaman beternak, dan peningkatan pengetahuan, serta peningkatan kemampuan manajemen usaha dan pengambilan keputusannya.Teknologi dan inovasi sangat dibutuhkan dalam pengembangan usaha rearing sapi perah, teknologi dan inovasi memungkinkan ditemukannya metode dan cara-cara kreatif dalam menujang pengembangan usaha yang berkelanjutan.

\section{Strategi Pemanfaatan Keunggulan Komparatif}

Pengembangan usaha rearing di wilayah baru tentunya perlu persiapan yang matang, karena terkait dengan pelibatan orang/ peternak dan budaya, karena itu persiapan lebih diarahkan pada pengkondisian dari aspek teknis, sosial dan budaya. Hasil penelitian yang telah diuraikan di atas, telah ditemukan beberapa keunggulan komparatif dan faktor penentu dalam pengembangan usaha rearing sapi perah di Jawa Barat. Temuan tersebut menjadi dasar berharga dalam menyusun strategi.

Strategi pemanfaatan keunggulan komparatif dalam penyediaan calon induk sapi perah di Jawa Barat diarahkan pada pengembangan usaha rearing sapi perah berkelanjutan yang didukung dengan berbagai kebijakan yang saling memperkuat satu sama lain.Fokus program diupayakan melalui pengembangan kualitas Pembinaan, kualitas SDM Peternak, peningkatan adopsi teknologi dan inovasi rearing sapi perah

\section{SIMPULAN}

Secara keseluruhan Keunggulan komparatif wilayah dalam pengembangan usaha rearing sapi perah menurut urutan tertinggi sampai terendah adalah: (a) ketersediaan pakan hijauan, (b) ketersediaan jumlah tenaga kerja, dan (c) ketersediaan pedet sapi perah betina.

Seluruh wilayah memiliki keunggulan komparatif yang berbeda-beda menurut indeks perbandingan relatif sumberdaya dalam pengembangan usaha rearing pedet sapi perah betina.

Faktor-faktor penentu dalam pengembangan sapi perah yang memiliki pengaruh besar dengan tingkat ketergantungan rendah adalah : (a) kebijakan pemerintah, (b) eksistensi petugas/ pembina, dan (c) sumberdaya manusia dan teknologi.

Strategi pemanfaatan keunggulan komparatif dalam penyediaan calon induk sapi perah di Jawa Barat diarahkan pada pengembangan usaha rearing sapi perah berkelanjutan yang didukung dengan berbagai kebijakan yang saling memperkuat satu sama lain. Fokus program diupayakan melalui pengembangan kualitas Pembinaan, kualitas SDM Peternak, peningkatan adopsi teknologi dan inovasi rearing sapi perah 


\section{UCAPAN TERIMA KASIH}

Terima kasih kami ucapkan kepada Pihak DIKTI yang memberikanbantuandanapenelitian dan Ketua dan Sekretaris LPPM Unpad beserta stafnya.

\section{DAFTAR PUSTAKA}

Astuti, M., Rini Widiati, Yustina Yuni Suranindyah, 2010. Efisiensi Produksi Sapi Perah (Studi kasus pada peternak Anggota Koperasi Usaha Peternakan dan Pemerahan Sapi Perah Kaliurang, Sleman Yogyakarta). Buletin Peternakan Vo; 34(1): 64-69. Februari 2010.

Direktorat Direktorat Jenderal Peternakan dan Kesehatan Hewan, 2011. Rencana Strategis Direktorat Jenderal Peternakan dan Kesehatan Hewan 2010-2014. Kementrian Pertanian. Direktorat Direktorat Jenderal Peternakan dan Kesehatan Hewan. http://www.pertanian. go.id/sakip/admin/file/RENSTRA DITJEN PKH_2010-2014.pdf. Diakses : 24/092014 : 13.41 .

Direktorat Jenderal Peternakan dan Kesehatan Hewan, 2014. Rancangan Keterpaduan Program dan Kegiatan Fokus Komoditas dan Lokasi Tahun 2015. Disampaikan Pada : Musrenbangtan Tahun 2014. Jakarta, 13 Mei 2014

Hendarto, E., dan Sri Mastuti, 1999. Studi Partisipasi Peternak Sapi Perah rakyat Bantuan Pemerintah di Kabupaten Banyumas Dalam Pengelolaan dan Pengemdalian Pencemaran Terhadap hasil Ternak
Berupa Susu. Animal Production. Vol. 1. No. 2. November 1999: 63-74. http://animalproduction. net/index.php/JAP/article/view/18. Dikases 24/09/2014: 14:21.

MC Clelland, D. C. 1987. Human Motivation. New York: Cambridge University Press, 1987.

Meredith, Geoffrey, et, al., 1992, Kewirausahaan, Teori dan Praktik (alih bahasa Andre Aspasayogi), Binaman Pressindo, Jakarta.

Mukson, T. Ekowati, M. Handayani dan D.W. Harjanti, 2009. Faktor-Faktor yang Mempengaruhi Kinerja Usahaternak Sapi Perah Rakyat di Kecamatan Getasan Kabupaten Semarang. Seminar Nasional Kebangkitan Peternakan: Pemberdayaan Peternakan Berbasis Sumber Daya Lokal untuk Ketahanan Pangan Nasional Berkelanjutan. Semarang, 20 Mei 2009. Universitas Diponogoro. Semarang.

Suryaningtyas, D., 2004. Membentuk Karakter Wirausahawan Yang Kreatif dan Tangguh. Jurnal Ekonomi dan Kewirausahaan Vol. 4, No. 1, April 2004 : $96-103$

Taslim 2011. Pengaruh Faktor Produksi Susu Usaha ternak Sapi Perah Melalui Pendekatan Analisis Jalur di Jawa Barat. Jurnal Ilmu Ternak. Juni 2011. No. 10 Vol. 1, 52-56.

Wasty Soemanto, 1992, Pendidikan Wiraswasta, Bumi Aksara, Jakarta.

Yusdja, Y., 2005. Kebijakan Ekonomi Industri Agribisnis Sapi Perah di Indonesia. Analisis Kebijakan Pertanian Volume 3 No. 3 2005: 257-268 